\title{
PKM Pengembangan Pasar Sulam Bordir Sumatera Barat Berbasis Web E-Commerce dalam Bingkai kearifan Lokal Minangkabau
}

\author{
Rose Rahmidani ${ }^{*}{ }^{1}$, Armiati $^{2}$, Syukhri ${ }^{3}$, Dessi Susanti ${ }^{4}$ \\ ${ }^{124}$ Pendidikan Ekonomi/ Fakultas Ekonomi/ Universitas Negeri Padang .124 \\ ${ }^{3}$ Teknik Elektronika / Fakultas Teknik/ Universitas Negeri Padang... 3 \\ *)Corresponding author, $\Xi$ rose_rahmidani@fe.unp.ac.id
}

Revisi 10/06/2019; Diterima 11/07/2019; Publish 08/08/2019

Kata kunci: Web ECommerce, Sulam Bordir, Pengembangan Pasar

\begin{abstract}
Abstrak
Kasih Bunda Bordir dan Ririn Bordir: 1) Tidak mampu merancang dan membuat web e-commerce usaha untuk melakukan pengembangan pasar, 2) Belum mampu mengoperasikan web e-commerce usaha untuk melakukan pengembangan pasar. Metode pendekatan yang digunakan adalah: 1) Menggunakan metode berbasis kebutuhan, tim kegiatan pengabdian mempercayakan kepada pakar Teknik Informatika untuk merancang dan membuatkan web ecommerce bagi Kasih Bunda Bordir dan Ririn Bordir sehingga terselenggaranya pengembangan pasar berbasis web e-commerce, sedangkan sarana penunjangnya berupa perangkat hardware disediakan oleh tim kegiatan pengabdian untuk Kasih Bunda Bordir dan Ririn Bordir, 2) Menggunakan metode ceramah, tanya jawab, diskusi, pemberian tugas, demonstrasi, dan tutorial. Hasil yang dicapai adalah: 1) Kasih Bunda Bordir dan Ririn Bordir memiliki web e-commerce usaha beserta sarana penunjangnya untuk pengembangan pasar yang semula hanya konsumen yang berada di wilayah pariaman berkembang ke daerah lain, 2) Kasih Bunda Bordir dan Ririn Bordir, mampu mengoperasikan web e-commerce usaha yang sudah disediakan, 3) Meningkatnya penjualan Kasih Bunda Bordir dan Ririn Bordir dibandingkan penjualan sebelum kegiatan pengabdian.
\end{abstract}

\section{PENDAHULUAN}

Hasil research yang penulis publish pada seminar international di Universitas Negeri Malang pada tahun 2017 yang berjudul Potency Creative Industry Sulam, Embroidery and Weaving in West Sumatera in Developing the Common Economy, diperoleh 93 profil pelaku usaha bordir/sulam dan pertenunan tersebar di 8 Kabupaten/kota di Sumatera Barat 
(termasuk Kota Pariaman), hasil penelitian menunjukkan bahwa pemasaran adalah salah satu persoalan besar dan urgen bagi pelaku usaha sulam/bordir di Sumatera Barat (Armiati dkk, 2017). Kemudian hasil research yang penulis publish pada seminar international di Universitas Pendidikan Indonesia tahun 2018 yang merupakan research lanjutan tahun 2017 menunjukkan bahwa strategi yang direkomendasikan untuk industri kreatif Sulaman dan Bordir di Sumatera Barat adalah Strategi Intensif (Armiati dkk, 2018). Salah satu strategi intensif tersebut adalah pengembangan pasar. Strategi intensif diantaranya adalah pengembangan pasar yang mengharuskan industri Bordir dan sulam di Sumatera Barat untuk mengadakan upaya-upaya intensif jika posisi kompetitif bordir dan sulam yang ada saat ini ingin membaik (Martinsons, 2008).

Pengembangan pasar tidak terlepas dari cara memasarkan, cara pemasaran tradisional masih menjadi andalan pelaku industri sulam dan bordir Sumatera Barat. Pusat perdagangan di Pasar Aur Kuning Bukittinggi dan Pasar Pariaman merupakan salah satu lokasi yang paling banyak didatangi pelanggan. Selain mengandalkan pusat perdagangan, para pelaku usaha juga mengikuti pameran yang diselenggarakan oleh daerah. Cara pemasaran yang tradisional ini sangat terbatas dalam penyampaian informasi hasil produk sulaman dan bordir.

Promosi yang telah dilakukan oleh industri Bordir dan sulam di Sumatera Barat yaitu melalui promosi dari mulut ke mulut, pameran dan brosur. Permasalahan yang ditemukan pada pelaku usaha bordir dan sulam Sumatera Barat terkait dengan terbatasnya promosi yang dilakukan. Pada umumnya pelaku usaha industri sulam dan bordir Sumatera Barat memasarkan produknya pada satu lingkup pasar saja tanpa menggunakan bantuan teknologi informasi khususnya internet. Hal ini disebabkan karena pelaku industri bordir dan sulam masih kesulitan dalam hal penguasaan teknologi informasi disamping banyak diantara mereka yang tidak memiliki personal computer seperti laptop. Banyak ditemukan pelaku usaha yang belum memiliki website atau blog sendiri sehingga media promosi yang digunakan sangat terbatas, sempitnya pangsa pasar dan tidak menjangkau khalayak yang luas.

Mengikuti pameran merupakan promosi yang sering dilakukan oleh industri Bordir dan sulam di Sumatera Barat. Promosi melalui pameran dinilai kurang efektif karena tidak semua orang dapat berkunjung ke pameran sehingga diperlukan promosi dalam bentuk lain. Promosi dapat dilakukan dalam berbagi bentuk seperti promosi sale force mengunakan iklan dimedia cetak maupun elektronik dan online (Kotler dan Amstrong, 2014). Promosi secara sale force dapat dilakukan karena tidak semua orang punya keinginan untuk berkunjung kegaleri Bordir dan sulam. Sehingga kehadiran sale force di ruang publik (mal, pusat pertokoan) dan lainnya dapat menjadi strategi untuk memasarkan produk secara agresif kepada konsumen. Iklan dimedia cetak dapat dilakukan dengan pemasangan iklan pada Koran dan majalah Fashion. Iklan yang paling mudah dan murah tersedia pada saat ini yaitu iklan online melalui website dan media sosial. Strategi iklan melalui internet saat ini telah menunjukkan peningkatan yang signifikan untuk semua jenis produk termasuk jenis pakaian. Sehinggga dengan meningkatkan promosi ke berbagai media dapat memperkenalkan bordir dan sulam ke ruang public yang lebih luas.

Strategi pengembangan pasar dapat dilakukan dengan memperkenalkan produk ke pasar yang baru (Kotler \& Keller, 2013). Selain pengembangan daerah pemasaran baru juga dapat dilakukan pengembangan segmentasi pelanggan. Fenomena yang tampak pada industri sulam dan bordir Sumatera Barat adalah pelaku industri sulam dan bordir sulit beradaptasi dengan struktur pasar yang ada. Pelaku industri pada umumnya kurang memiliki informasi pasar sebagai akibat keterbatasan kemampuan yang dimiliki sehingga mempersulit pelaku industri sulam dan bordir dalam memperluas akses pasar. Akibatnya, ruang gerak industri sulam dan bordir Sumatera Barat secara ekonomis akan tetap lemah dan terbatas. 


\section{Suluah Bendang: Jurnal IImiah Pengabdian Kepada Masyarakat}

Hal ini tentu berimbas pada semakin memburuknya posisi kompetitif sulam bordir Sumatera Barat. Salah satu upaya sebagai solusi dari permasalahan tersebut adalah melalui pengembangan pasar berbasis Web E-Commerce. Whitten (2004:21), mendefinisikan ecommerce sebagai pembelian dan penjualan barang dan layanan dengan menggunakan internet. Perdagangan elektronik atau e-commerce: Electronic commerce, terdiri dari penyebaran, pembelian, penjualan, pemasaran barang dan jasa melalui sistem elektronik seperti internet atau televisi, world wide web (www), atau jaringan komputer lainnya.

E-commerce dibagi menjadi 4, yaitu: 1) Bussines to Consumer (B2C), informasi disebarkan secara umum dan service juga bersifat umum, sehingga mekanismenya dapat digunakan oleh orang banyak. Service yang diberikan adalah berdasarkan permintaan. Konsumen berinisiatif sedangkan produsen harus siap memberikan respon terhadap inisiatif konsumen tersebut; 2) Bussines to Bussines (B2B); 3)Consumer to Consumer (C2C), Sebagian besar pemasaran online konsumen ke konsumen dan komunikasi terjadi di web antara pihak yang berminat atas kisaran luas produk dan subjek. Dalam beberapa kasus, internet menyediakan alat yang sangat baik di mana konsumen dapat membeli atau menukarkan barang atau informasi secara satu sama lain. Misal Tokobagus.com, FJB kaskus.co.id,; 4) Consumer to Bussines (C2B)Tempat pemasaran online yang terakhir adalah pemasaran online konsumen ke bisnis (Whitten, 2004). Berkat internet, konsumen lebih mudah berkomunikasi dengan perusahaan. Sekarang sebagian besar perusahaan mengundang prospek dan pelanggan untuk mengirimkan saran dan pertanyaan melalui web perusahaan (Kotler, 2013 : 238-241).

Web E-Commerce memiliki peran penting dalam memperluas akses pasar yang berimbas meningkatkan omzet penjualan. Makin ketatnya persaingan, mengharuskan dunia usaha secara terus menerus melakukan efisiensi, meningkatkan kualitas produk, pelayanan serta inovasi baru. Efisiensi dilakukan secara total mulai dari perencanaan, proses produksi, pemasaran dan pendistribusian dengan menggunakan internet bisa mengurangi biaya staf infrastruktur dan biaya lainnya yang biasanya harus dibayar oleh perusahaan tradisional. Bila industri sulam dan bordir Sumatera Barat tidak mengubah cara bisnisnya maka sulit untuk bisa bersaing dengan industri sulam dan bordir lain yang tersebar di Indonesia bahkan mancanegara yang mampu menawarkan barang yang sama dengan harga yang lebih murah.

Berdasarkan potret hasil research 2017-2018 di atas diketahui bahwa kebutuhan mendesak yang dirasakan oleh pengusaha sulam bordir di Sumatera Barat Umumnya dan Pariaman Khususnya adalah:

1) Pengusaha sulam bordir tidak mampu merancang dan membuat web e-commerce usaha untuk melakukan pengembangan pasar dalam bingkai kearifan lokal minangkabau guna meningkatkan penjualan dan kesejahteraan masyarakat pariaman yang merupakan sentra industri kreatif sulam bordir terbesar di sumatera Barat.

E-Commerce telah dengan cepat menjamur, bahkan di negara-negara berkembang. Meskipun saat ini banyak akademisi yang menyoroti isu-isu global, namun penelitian $E$ Commerce tak kalah mendapat perhatian yang luar biasa di negara-negara maju, seperti Inggris (Martinsons, 2008; Dai \& Palvi, 2009; Mangiaracina Etc, 2015). Manfaat yang dirasakan perusahaan khususnya untuk kepentingan pelanggan memperlihatkan bahwa $E$ Commerce dapat memberikan manfaat antara lain: mendapatkan pelanggan baru, menarik konsumen untuk tetap bertahan, meningkatkan mutu layanan, dan melayani konsumen tanpa batas waktu (Martinsons, 2008; Nemat, 2011; Yu, X. Etc.,2011; Hande, P. V., \& Ghosh, D, 2015, Chen, D. N., Etc, 2008; Leong, C. M. L., Etc, 2016). Penelitian yang dilakukan tentang E-Commerce diantaranya yaitu pemanfaatan E-Commerce untuk produk-produk unggulan di Malaysia (Kassim, N., \& Asiah, N, 2010). 
2) Pengusaha sulam bordir belum mampu mengoperasikan web e-commerce usaha untuk melakukan pengembangan pasar dalam bingkai kearifan lokal minangkabau.

Berpijak pada kebutuhan mendesak yang dirasakan oleh pengusaha sulam bordir pariaman yang merupakan sentra industri kreatif sulam bordir terbesar di sumatera Barat. Sehingga sangatlah tepat bila pengusaha sulam bordir dibekali dengan:

1) Web E-Commerce usaha yang sudah dirancang dan dibuat oleh ahlinya beserta sarana penunjangnya guna membantu pengusaha sulam bordir Pariaman untuk melakukan pengembangan pasar dalam bingkai kearifan lokal minangkabau guna meningkatkan penjualan dan kesejahteraan masyarakat pariaman yang merupakan sentra industri kreatif sulam bordir terbesar di sumatera Barat

2) Pelatihan dan workshop mengoperasikan web e-commerce usaha yang sudah disediakan untuk melakukan pengembangan pasar dalam bingkai kearifan lokal minangkabau.

Uraian kegiatan pengabdian kepada masyarakat ini meliputi: 1) Tahap Persiapan, kegiatannya adalah: a) Penentuan jadwal konkrit bersama mitra setelah usulan kegiatan disetujui untuk dilaksanakan, b) Koordinasi dengan Lurah, Kasih Bunda Bordir dan Ririn Bordir untuk pengurusan izin pelaksanaan kegiatan, c) Menghubungi narasumber dan menyesuaikan jadwal pelaksanaan, d) Menyediakan modul pengoperasian Web E-Commerce yang dibuat narasumber untuk dibagikan kepada mitra, 2) Pelaksanaan kegiatan, kegiatannya yaitu: a) Membantu Kasih Bunda Bordir dan Ririn Bordir merancang dan membuatkan web e-commerce usaha untuk melakukan pengembangan pasar sekaligus menyediakan sarana penunjangnya untuk terselenggaranya pengembangan pasar dalam bingkai kearifan lokal minangkabau guna meningkatkan penjualan dan kesejahteraan masyarakat pariaman yang merupakan sentra industri kreatif sulam bordir terbesar di sumatera Barat, b) Pelatihan dan workshop bagi Kasih Bunda Bordir dan Ririn Bordir dalam mengoperasikan web e-commerce usaha yang sudah disediakan untuk melakukan pengembangan pasar, 3) Tahap akhir kegiatan, evaluasi kegiatan dilakukan untuk masing-masing tahap dengan mengumpulkan dan menyimpulkan data dari masing-masing tahapan kegiatan. Hasil kegiatan PKM menunjukkan tingkat keberhasilan dengan indikasi adanya: 1) Respon yang positif dari Kasih Bunda Bordir dan Ririn Bordir, 2) Kasih Bunda Bordir dan Ririn Bordir memiliki masing-masing 1 web e-commerce usaha untuk terselenggaranya pengembangan pasar dalam bingkai kearifan lokal minangkabau beserta sarana penunjangnya dan meningkatnya pangsa pasar yang semula hanya konsumen yang berada di wilayah pariaman berkembang ke daerah lain seperti Bukittinggi, Padang dan Pekanbaru (pangsa pasar berkembang dari 1 daerah menjadi 3 daerah), 3) Kasih Bunda Bordir dan Ririn Bordir, 2 pelaku usaha sulam bordir tersebut mampu mengoperasikan web $e$ commerce usaha yang sudah disediakan.

Kegiatan pengabdian ini dilaksanakan di Kasih Bunda Bordir yang beralamat di jalan Syech Burhanudin Desa Karan Aur Kecamatan Pariaman Tengah Kota Pariaman Sumatera Barat dan Ririn Bordir yang beralamat di Desa Kampung Gadang Kecamatan Pariaman Timur Kota Pariaman Sumatera Barat. Kegiatan pengabdian ini dilaksanakan pada bulan April - Agustus 2019.

Kegiatan pengabdian ini menghasilkan Web e-commerce dengan muatan kearifan lokal minangkabau, yang memanfaatkan Teknologi Informasi dan Komunikasi yang berguna sebagai media bagi pelaku usaha sulam/bordir di Sumatera Barat untuk mempromosikan dan memperkenalkan produknya ke pasar yang baru, sehingga dapat memperluas dan mengembangkan pasarnya. Dengan luasnya pasar yang dapat dimasuki oleh pelaku industri sulam dan bordir Sumatera Barat maka hal ini meningkatkan daya saing industri kreatif unggulan Sumatera Barat di pasar nasional dan internasional sehingga eksistensinya meningkatkan kontribusi sektor industri kerajinan dalam peningkatan pertumbuhan ekonomi Sumatera Barat khususnya dan Indonesia umumnya, sekaligus sebagai upaya pelestarian 


\section{Suluah Bendang: Jurnal Ilmiah Pengabdian Kepada Masyarakat}

Vol.19, No.3, 2019

Rose Rahmidani 1, Armiati2, Syukhri3, Dessi Susanti4

budaya lokal yang bersinergi dengan kemajuan teknologi yang seyogyanya membawa bangsa Indonesia menjadi masyarakat ekonomi kreatif yang berkarakter budaya. Pengembangan ekonomi berbasis digital harus diarahkan berbasis kearifan lokal atau kekuatan ekonomi rakyat. Tanpa itu, pengaruhnya bagi peningkatan kesejahteraan masyarakat tidak akan signifikan (Mukhlis, 2017).

Target dari kegiatan pengabdian kepada masyarakat ini adalah: 1) Kasih Bunda Bordir dan Ririn Bordir memiliki masing-masing 1 web e-commerce usaha beserta sarana penunjangnya untuk terselenggaranya pengembangan pasar dalam bingkai kearifan lokal minangkabau dan meningkatnya pangsa pasar yang semula hanya konsumen yang berada di wilayah pariaman berkembang ke daerah lain seperti Bukittinggi, Padang dan Pekanbaru (pangsa pasar berkembang dari 1 menjadi 3 daerah), 2) Kasih Bunda Bordir dan Ririn Bordir, 2 usaha sulam bordir tersebut mampu mengoperasikan web e-commerce usaha yang sudah disediakan untuk melakukan pengembangan pasar dalam bingkai kearifan lokal minangkabau.

\section{METODE PELAKSANAAN}

Metode pendekatan yang digunakan dalam kegiatan pengabdian kepada masyarakat ini adalah sebagai berikut: 1) Membantu Kasih Bunda Bordir dan Ririn Bordir merancang dan membuatkan web e-commerce usaha untuk melakukan pengembangan pasar sekaligus menyediakan sarana penunjangnya untuk terselenggaranya pengembangan pasar dalam bingkai kearifan lokal minangkabau guna meningkatkan penjualan dan kesejahteraan masyarakat pariaman yang merupakan sentra industri kreatif sulam bordir terbesar di sumatera Barat, dalam hal ini digunakan pendekatan berbasis kebutuhan, tim kegiatan pengabdian mempercayakan kepada pakar Teknik Informatika untuk merancang dan membuatkan web e-commerce bagi Kasih Bunda Bordir dan Ririn Bordir sehingga terselenggaranya pengembangan pasar berbasis web e-commerce dalam bingkai kearifan lokal minangkabau, sedangkan sarana penunjangnya berupa perangkat hardware disediakan oleh tim kegiatan pengabdian untuk Kasih Bunda Bordir dan Ririn Bordir, 2) Pelatihan dan workshop bagi Kasih Bunda Bordir dan Ririn Bordir selaku pengusaha sulam bordir Kota Pariaman dalam mengoperasikan web e-commerce usaha yang sudah disediakan untuk melakukan pengembangan pasar dalam bingkai kearifan lokal minangkabau, untuk ini digunakan metode ceramah, tanya jawab, diskusi, pemberian tugas, demonstrasi, dan tutorial.

Mitra sekaligus yang menjadi khalayak sasaran kegiatan pengabdian masyarakat ini adalah Kasih Bunda Bordir dan Ririn Bordir selaku pengusaha sulam bordir Kota Pariaman. Kerjasama dengan mitra ditandatangani oleh Pemilik usaha Kasih Bunda Bordir dan Ririn Bordir. Partisipasi mitra dalam pelaksanaan program adalah: a) Menyediakan tempat pelatihan dan workshop, b) Menyediakan peralatan pendukung lainnya untuk kelancaran kegiatan pengabdian ini.

Untuk mengetahui sejauhmana tujuan dapat dicapai maka diadakan evaluasi. Evaluasi dilakukan dalam tiga tahap yang meliputi evaluasi persiapan, evaluasi proses dan evaluasi hasil. Rancangan evaluasi tersebut dapat dijelaskan sebagai berikut: 1) Evaluasi input, dilakukan dengan cara mengadakan tanya jawab untuk mengetahui sejauhmana pengetahuan awal Kasih Bunda Bordir dan Ririn Bordir selaku pengusaha sulam bordir Kota Pariaman terkait Web ECommerce sehingga apa yang diberikan dan disampaikan efektif, 2) Evaluasi proses, dilakukan dengan cara melihat antusias, motivasi dan kreativitas Kasih Bunda Bordir dan Ririn Bordir selaku pengusaha sulam bordir Kota Pariaman mengikuti kegiatan. Hal ini penting dilakukan untuk mengevaluasi kebermaknaan program/kegiatan, 3) Evaluasi output, dilakukan terhadap luaran dari kegiatan yang dilakukan, meliputi evaluasi terhadap Web E-Commerce usaha yang sudah dirancang dan dihasilkan untuk melakukan pengembangan pasar dalam bingkai kearifan 
lokal minangkabau guna meningkatkan penjualan dan kesejahteraan masyarakat pariaman yang merupakan sentra industri kreatif sulam bordir terbesar di Sumatera Barat. Selain itu juga dilakukan evaluasi terhadap Kasih bunda bordir dan Ririn bordir dalam mengoperasikan Web E-Commerce usaha yang sudah disediakan. Selanjutnya diberikan angket kepada mitra untuk mengetahui pendapat mitra tentang kegiatan yang sudah dilakukan.

Setelah kegiatan PKM ini dilaksanakan, maka keberlanjutan program ini dapat diteruskan oleh Kasih Bunda Bordir dan Ririn Bordir selaku pengusaha sulam bordir Kota Pariaman, dengan cara mengaplikasikannya secara terus menerus serta menularkannya kepada pengusaha sulam bordir yang lain. Dan tim pengabdian sebagai pelaksana kegiatan PKM tetap melakukan interaksi dengan Kasih Bunda Bordir dan Ririn Bordir sebagai mitra guna memantau keberlanjutan program ini

\section{HASIL DAN PEMBAHASAN}

Kegiatan pengabdian masyarakat ini membekali kasih bunda bordir dan ririn bordir dengan: 1) Web E-Commerce usaha yang sudah dirancang dan dibuat oleh ahlinya beserta sarana penunjangnya guna membantu pengusaha sulam bordir Pariaman untuk melakukan pengembangan pasar dalam bingkai kearifan lokal minangkabau guna meningkatkan penjualan dan kesejahteraan masyarakat pariaman yang merupakan sentra industri kreatif sulam bordir terbesar di sumatera Barat.

Web E-Commerce yang dirancang oleh ahlinya untuk pelaku usaha Kasih Bunda bordir dan Ririn bordir Kota Pariaman diawali dengan melakukan analisis kebutuhan (need assessment) oleh tim kegiatan pengabdian dan ahli. Adapun tahapan dalam melakukan analisis ini yaitu melakukan diskusi, wawancara dan tanya jawab dengan Kasih Bunda bordir dan Ririn bordir.

Diskusi dengan Ririn bordir dilakukan pada tanggal 20 April 2019. Diskusi dilakukan di tempat usaha Ririn bordir yang beralamat di Jalan By Pass Padusunan Kampung Gadang Samping Kampus STIE Sumbar Dekat Hotel Almadinah. Hasil diskusi yaitu Ririn bordir membutuhkan Web E-Commerce yang memuat ciri khas daerah Pariaman. Adapun ciri khas daerah pariaman yang menjadi kearifan lokalnya adalah pada motif batang karambia, angso duo dan tabuik. Ini adalah kearifan lokal yang merupakan kekuatan industri kreatif sulam bordir pariaman yang tidak dimiliki oleh daerah lain di Sumatera Barat. Sehingga disetiap sulam/bordir dan kerajinan lainnya, selalu memuat motif tersebut. Ciri khas bordir kota Pariaman dapat dijadikan kekuatan dalam rancangan Web E-Commerce Ririn bordir.
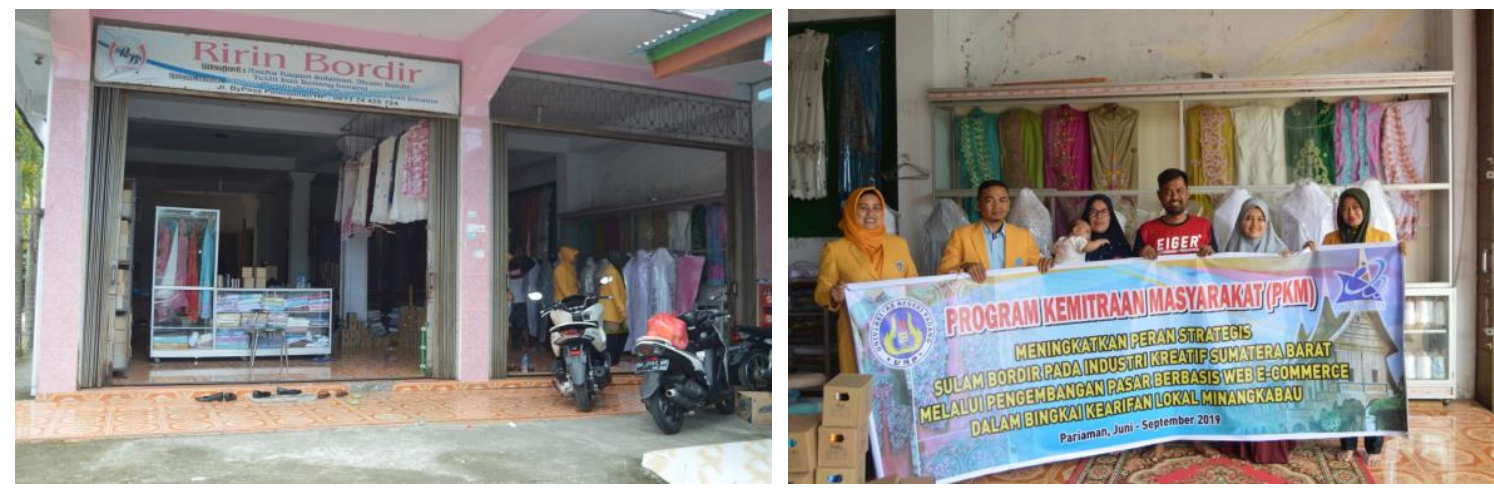

Gambar 1. 2. Kunjungan ke tempat usaha Ririn Bordir dalam rangka need analysis 


\section{Suluah Bendang: Jurnal Ilmiah Pengabdian Kepada Masyarakat}

Vol.19, No.3, 2019

Rose Rahmidani 1, Armiati2, Syukhri3, Dessi Susanti4

Diskusi dengan Kasih Bunda bordir dilakukan pada tanggal 15 Juni 2019. Diskusi dilakukan di tempat usaha Kasih Bunda bordir yang beralamat di Jalan Syech Burhanudin, komplek perumahan Samudera Indah No. 9, Belakang mesjid Raya Karan Aur Pariaman Tengah. Hasil diskusi yaitu Kasih bunda bordir membutuhkan Web E-Commerce yang memuat ciri khas daerah Pariaman. Adapun ciri khas daerah pariaman yang menjadi kearifan lokalnya adalah pada motif batang karambia, angso duo dan tabuik. Ini adalah kearifan lokal yang merupakan kekuatan industri kreatif sulam bordir pariaman yang tidak dimiliki oleh daerah lain di Sumatera Barat. Sehingga disetiap sulam/bordir dan kerajinan lainnya, selalu memuat motif tersebut. Ciri khas bordir kota Pariaman dapat dijadikan kekuatan dalam rancangan Web ECommerce Kasih Bunda bordir.
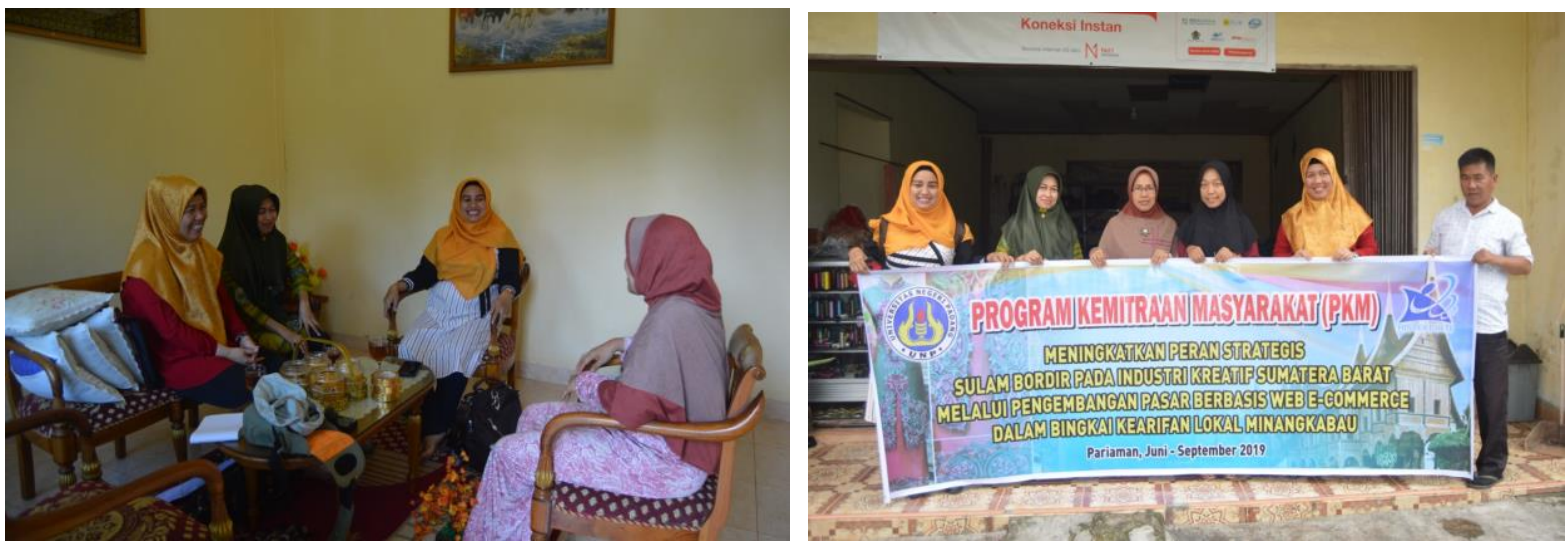

Gambar 3. 4. Kunjungan ke tempat usaha Kasih Bunda Bordir dalam rangka need analysis

Setelah dilakukan analisis kebutuhan langkah selanjutnya adalah membuat rancangan Web E-Commerce Kasih Bunda bordir dan Ririn Bordir. Web E-Commerce Kasih Bunda bordir dan Ririn Bordir dirancang oleh ahli dibidang teknik informatika. Didalam merancang Web ECommerce dibutuhkan data-data terkait dengan usaha Kasih Bunda bordir dan Ririn Bordir. Data-data tersebut diperoleh melalui diskusi, wawancara dan tanya jawab dengan Kasih Bunda bordir dan Ririn bordir.

Diskusi dengan Ririn bordir dilakukan pada tanggal 21 Juli 2019 dan Kasih Bunda bordir pada tanggal 27 Juli 2019. Diskusi dilakukan di tempat usaha Ririn bordir dan Kasih Bunda bordir. Hasil diskusi yaitu: 1) Ririn bordir dan Kasih Bunda bordir harus membuat logo produk yang jelas sebagai fitur yang harus ada dalam Web E-Commercenya, sebuah logo yang jelas dan luar biasa adalah kartu nama bagi pelaku usaha online. Ketika datang kebelanja online logo yang dikenali adalah simbol yang meyakinkan dan unsur kepercayaan dari perusahaan atau organisasi tersebut; 2) Ririn bordir dan Kasih Bunda bordir harus membuat merek produk yang jelas, ini adalah fitur yang harus ada dalam home page web e-commerce; 3) Alamat, telepon dan kontak lain dari Ririn bordir dan Kasih Bunda bordir harus tersaji di dalam Webnya; 4) Deskripsi yang jelas tentang Ririn bordir dan Kasih Bunda bordir, harus tersedia pada web e-commercenya. Ririn bordir dan Kasih Bunda bordir perlu memberikan story telling ataupun penjelasan tentang bisnisnya dan siapa orang-orang dibaliknya. Hal tersebut akan mengesankan kepada konsumen bahwa bisnis yang dia jalankan adalah benar dan bukan bentuk penipuan. Sebuah deskripsi yang jelas akan menarik perhatian para pengunjung; 5) Ririn bordir dan Kasih Bunda bordir harus memberikan deskripsi yang jelas tentang produkproduknya secara detail, mulai dari nama barang, nama bahan, variasi produk dan lain-lain; 6) Kebijakan pengembalian barang, Ririn bordir dan Kasih Bunda bordir harus menentukan 
kebijakan pengembalian yang merupakan fitur penting dari setiap website toko online karena merupakan salah satu fitur untuk meningkatkan kepercayaan pelanggan. Fitur ini meyakinkan pembeli bahwa Ririn bordir bersedia bertanggung jawab jika ada kesalahan pengiriman, produk yang rusak atau tidak sesuai dan sebagainya; 7) dan hal-hal lain yang dirasa perlu.

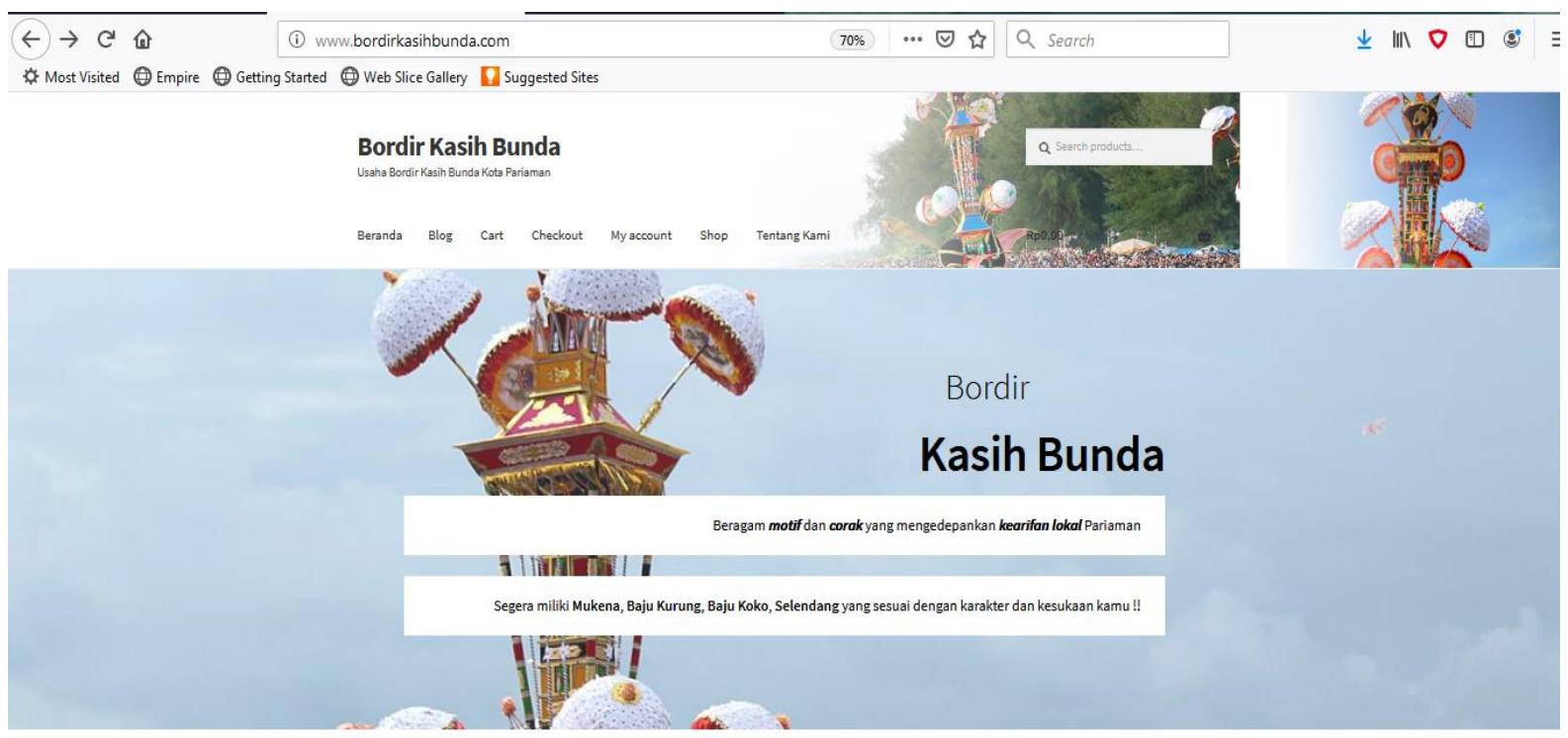

Belanja berdasarkan Kategori

Gambar 5. Hasil rancangan awal Web E-Commerce Kasih Bunda Bordir Alamat Link: www.bordirkasihbunda.com

\begin{tabular}{|c|c|c|c|c|}
\hline$f \rightarrow C \hat{0}$ & (i) www.rinhbordir.com & $\cdots \nabla \hat{\natural}$ & $Q_{\text {Search }}$ & $\underline{\downarrow} \mathbb{\|} \cap 0 \mathbb{\theta}$ \\
\hline
\end{tabular}

Ririn Bordir

Mukena Bordir Khas Pariaman

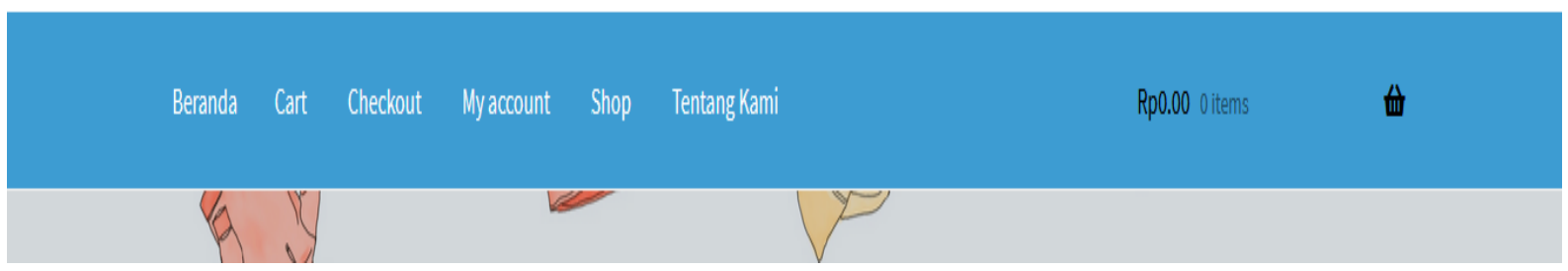

Gambar 6. Hasil rancangan awal Web E-Commerce Ririn Bordir Alamat Link: www.ririnbordir.com

3) Pelatihan dan workshop mengoperasikan web e-commerce usaha yang sudah disediakan untuk melakukan pengembangan pasar dalam bingkai kearifan lokal minangkabau. Pelatihan dan workshop mengoperasikan web e-commerce usaha Kasih bunda bordir dan Ririn bordir di tujukan bagi operator. Operator dalam hal ini merupakan SDM yang tugasnya 


\section{Suluah Bendang: Jurnal Ilmiah Pengabdian Kepada Masyarakat}

Rose Rahmidani 1, Armiati2, Syukhri3, Dessi Susanti4

mengoperasikan menghidupkan hardware, menjalankan Web E-Commerce, berinteraksi dengan hardware dan Web E-Commerce yang sedang beroperasi, dan menyudahi operasi (menghentikan software dan mematikan hardware) (Nugroho, 2009). Pelatihan dan workshop mengoperasikan web e-commerce Kasih bunda bordir dan Ririn bordir menitik beratkan pada aspek fitur-fitur yang ada di dalam Web E-Commerce Kasih bunda bordir dan Ririn bordir yang merupakan layanan yang diberikan oleh Kasih Bunda bordir dan Ririn bordir di dalam websitenya. Fitur-fitur tersebut adalah: 1) Fitur Untuk Melihat detail produk, Pada umumnya, calon pembeli akan lebih yakin dengan produk yang dipromosikan baik melalui video maupun dipromosikan lewat foto. Fitur khusus ini mempermudah pengunjung website melihat detail produk; 2) Fitur Untuk Melihat Kumpulan Foto Produk, Kebanyakan pengunjung website yang ingin membeli sesuatu akan fokus pada foto produk terlebih dahulu. Setelah mereka melihat foto produk, baru pengunjung website melihat spesifikasi atau ulasan tentang produk. Pastinya pengunjung website akan merasa sangat terbantu jika ada fitur yang membantu mereka langsung melihat kumpulan foto produk; 3 ) Fitur Tansaksi Pembayaran, jika ingin membeli sebuah produk di salah satu website, pastinya akan lebih menyenangkan jika transaksi pembayaran bisa langsung dilakukan. Fitur transaksi pembayaran akan mempermudah siapa saja yang ingin membeli tanpa mau repot; 4) Fitur Pengiriman Barang, produk yang dijual dengan cara bisnis online biasanya harus melalui proses pengiriman barang. Proses pengiriman barang ini biasanya cukup membuat pembeli merasa khawatir. Hal ini dikarenakan pembeli merasa takut jika barang yang dipesan tidak datang tepat waktu. Fitur ini adalah fitur yang mengatur proses pengiriman barang pada pembeli. Dengan adanya fitur ini, pembeli akan merasa jauh lebih tenang; 5) Fitur Frequently Asked Question, terkadang hanya melihat spesifikasi barang secara umum tidak membuat pengunjung Website yakin untuk membeli. Melalui fitur ini, pengunjung website bisa mengetahui spesifikasi produk lebih detail. Bahkan pengunjung bisa langsung berinteraksi dengan admin untuk bertanya tentang spesifikasi lebih detail; 6) Fitur Review Pelanggan, fitur ini memungkinkan calon pembeli melihat review produk dari para pelanggan yang lebih dulu sudah membeli produk. Pemberian review ini juga berbeda-beda. Ada pemberian review berupa bintang. Sehingga pelanggan yang telah membeli produk bisa memberikan penilaian dengan pemberian bintang. Jumlah bintang ini biasanya akan menjadi pertimbangan khusus.
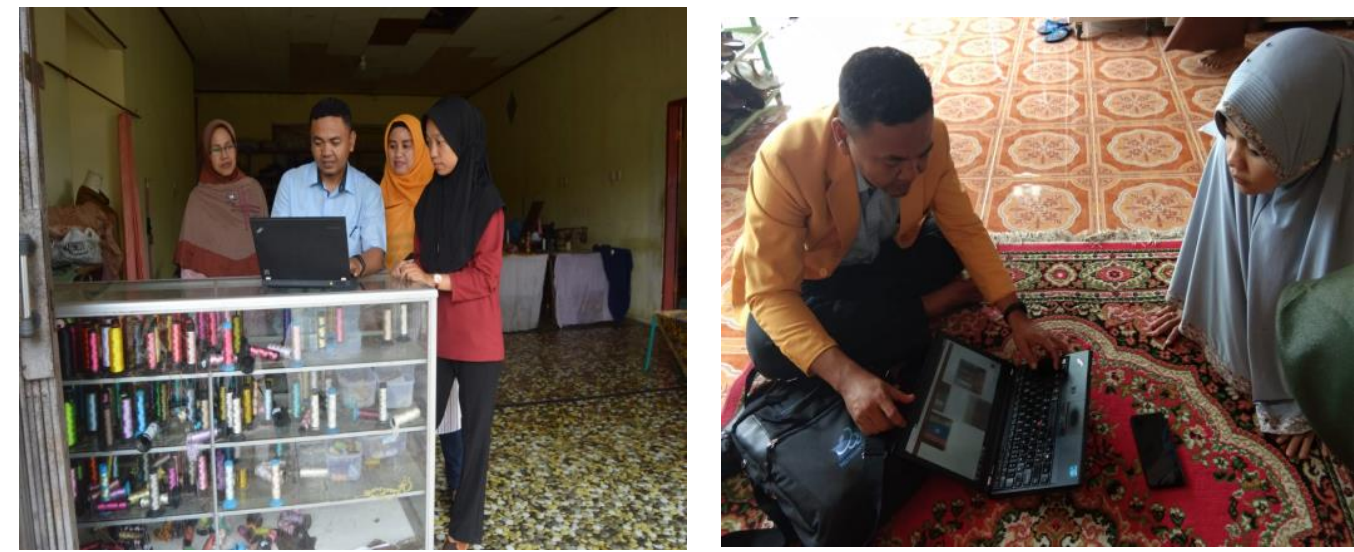

Gambar 7.8. Pelatihan dan workshop mengoperasikan Web E-Commerce di Kasih Bunda Bordir dan Ririn Bordir 
Kegiatan pengabdian masyarakat ini berjalan dengan sukses dan lancar karena mendapatkan respon positif dari pihak mitra yaitu Kasih Bunda Bordir dan Ririn Bodir. Menurut mereka kegiatan ini sangat memberikan dampak positif bagi usaha bordir yang sedang mereka geluti. Dampak kegiatan ini adalah 1) Meningkatkan pengetahuan Kasih Bunda bordir dan Ririn bordir terhadap IT, dalam hal ini adalah E-Commerce. Hal ini sangat berperan dalam rangka melakukan pengembangan pasar dalam bingkai kearifan lokal minangkabau guna meningkatkan penjualan dan kesejahteraan kasih bundan bordir dan ririn bordir sekaligus masyarakat kota pariaman yang merupakan sentra industri kreatif sulam bordir terbesar di sumatera Barat. 2) Meningkatkan skill Kasih Bunda Bordir dan Ririn Bordir dalam mengoperasikan web e-commerce usaha yang sudah disediakan untuk melakukan pengembangan pasar. 3) Kasih Bunda Bordir dan Ririn Bordir memiliki masing-masing 1 web ecommerce usaha beserta sarana penunjangnya untuk terselenggaranya pengembangan pasar dalam bingkai kearifan lokal minangkabau dan meningkatnya pangsa pasar yang semula hanya konsumen yang berada di wilayah pariaman berkembang ke daerah lain.

Kasih Bunda Bordir dan Ririn Bordir sebagai peserta kegiatan PKM memiliki motivasi yang tinggi dan sangat antusias mengikuti kegiatan ini sehingga komit untuk memaksimalkan penggunaan Web E-Commerce usaha yang sudah disediakan dalam rangka pengembangan pasar dalam bingkai kearifan lokal minangkabau. berikut:

Berdasarkan evaluasi yang telah dilakukan dapat diajukan beberapa saran sebagai

1. Kegiatan lanjutan yang berupa pelatihan dan workshop sejenis selalu diselenggarakan secara periodik terhadap pelaku usaha industri kreatif khususnya sulam bordir di Sumatera Barat, agar semakin membaiknya posisi kompetitif sulam bordir Sumatera Barat.

2. Melalui kegiatan pelatihan dan workshop ini, diharapkan Kasih Bunda Bordir dan Ririn Bordir menerapkan ilmu yang diperoleh, sehingga mampu tampil sebagai pelaku usaha yang berperan dalam meningkatkan kontribusi sektor industri kerajinan dalam peningkatan pertumbuhan ekonomi Sumatera Barat

\section{DAFTAR PUSTAKA}

Armiati, A., Rahmidani, Rose., Susanti, Dessi. (2017). Potency of Creative Industry Sulam, Embroidery and Weaving in West Sumatera in Developing the Common Economy. International Research Conference on Economics and Business, "Facing Future Economics: Challenges and Perspectives". Hal. 37. ISBN 978-602-50785-0-7.

Armiati, A., Rahmidani, Rose., Susanti, Dessi. (2018). Pemetaan, Needs Assessment Dan Model Pengembangan Industri Kreatif Unggulan Bordir/Sulam Dan Pertenunan Di Sumatera Barat Sebagai Khasanah Dan Warisan Budaya Minangkabau. Laporan Penelitian Strategi Nasional Institusi (STRANAS-INSTITUSI) DRPM.

Chen, D. N., Jeng, B., Lee, W. P., \& Chuang, C. H. (2008). An agent-based model for consumer-tobusiness electronic commerce. Expert Systems with Applications, 34(1), 469-481.

Dai, H., \& Palvi, P. C. (2009). Mobile commerce adoption in China and the United States: a crosscultural study. ACM SIGMIS Database: the DATABASE for Advances in Information Systems, 40(4), 43-61.

Hande, P. V., \& Ghosh, D. (2015). A comparative study on factors shaping buying behaviour on $B 2 B$ and B2C E-commerce platforms in India. EXCEL International Journal of Multidisciplinary Management Studies, 5(3), 1-10. 


\section{Suluah Bendang: Jurnal Ilmiah Pengabdian Kepada Masyarakat}

Kassim, N., \& Asiah Abdullah, N. (2010). The effect of perceived service quality dimensions on customer satisfaction, trust, and loyalty in e-commerce settings: A cross cultural analysis. Asia Pacific Journal of Marketing and Logistics, 22(3), 351-371.

Kotler, Philip dan Amstrong, Gary, (2014), Principles of Marketin, 12th Edition,Jilid 1 Terjemahan Bob Sabran Jakarta : Erlangga.

Kotler, Philip dan Keller, Kevin Lane, (2013), Marketing Management, 14th Edition, Pearson Education Limited.

Leong, C. M. L., Pan, S. L., Newell, S., \& Cui, L. (2016). The Emergence of Self-Organizing ECommerce Ecosystems in Remote Villages of China: A Tale of Digital Empowerment for Rural Development. Mis Quarterly, 40(2), 475-484.

Mangiaracina, R., Marchet, G., Perotti, S., \& Tumino, A. (2015). A review of the environmental implications of B2C e-commerce: a logistics perspective. International Journal of Physical Distribution \& Logistics Management, 45(6), 565-591.

Martinsons, M. G. (2008). Relationship-based e-commerce: theory and evidence from China. Information Systems Journal, 18(4), 331-356.

Mukhlis, Imam. (2017). Global Innovation Index Conference. diakses tanggal 22 Oktober 2018 melalui https://www.kemenperin.go.id/artikel/18169/Pemerintah-KembangkanEkonomi-Digital-Berbasis-Industri-dan-e-Commerce

Nemat, R. (2011). Taking a look at different types of e-commerce. World Applied Programming, 1(2), 100-104.

Nugroho, Endro. 2009. Buku Pintar Jaringan Komputer. Modeoms. Yogjakarta

Whitten, Jeffry L., Lonnie D. Bentley., Kevin C. Dittman.2004. Metode Desain \& Analisis Sistem, Edisi keenam. Yogyakarta:Penerbit Andi

Yu, X., Guo, S., Guo, J., \& Huang, X. (2011). Rank B2C e-commerce websites in e-alliance based on AHP and fuzzy TOPSIS. Expert Systems with Applications, 38(4), 3550-3557. 